\title{
Godhead and humankind: The New Testament in unison with creedal Christianity
}

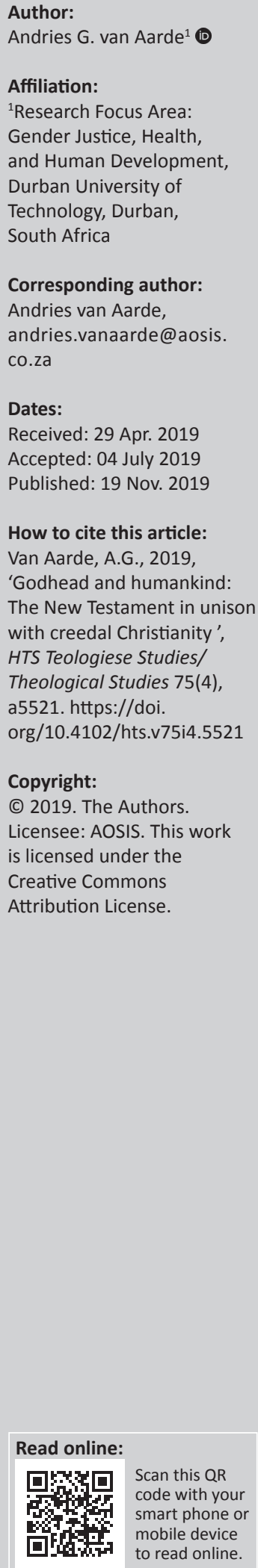

The aim of this article is to argue that the sharing of 'being' between Jesus and the Godhead, professed in creedal Christianity and based on the Nicaean creed, pertains to a 'sameness in divine substance'. This substance refers to divine wisdom, justice and mercy. The article attempts to demonstrate that there exists a congruence between textual evidence in the New Testament and these 'orthodox' belief tenets, especially represented in the Athanasian creed. This is explained in terms of an analysis of the origins and development of creedal formulae. This process represents a movement from a fundamental religious experience to a 'use' of metaphorical language, to the origins of confessional formulae that lead to the formulation of dogma. In light of the insight into the 'building blocks' of the formation of confessional formulae, the article concludes with a 'deconstruction' of the concepts 'anathematisation' and 'heresy'.

Keywords: creedal Christianity; Jesus tradition; Jesus; Paul; Nicea; Athanasisus; anathema; heresy.

\section{Footprints of tradition}

In a forthcoming two-volume work to be published by Cambridge Scholars Publications, I aim to demonstrate a congruence in the thought-substance shared by the peasant Jesus, the apostle Paul and the rabbi Matthew. In this article, my aim is to argue that this is a tenet which is also explicitly found in the writings of patristic theologians such as Athanasius of Alexandria (c. 296/298 CE-373 CE) and John of Damascus (c. 675/676-749 CE) - theologians who could be described as among the pioneers of Christian orthodoxy. Modern theologians who continue this truism are, among others, Friedrich Schleiermacher (1768-1834) and Rudolf Bultmann (1884-1976). Here, I would like to explore the footprints (i.e. genealogy) of this 'creedal' tradition in the Jesus tradition.

Viewed chronologically, almost all the constructs that critics have painted of Jesus begin with the baptism of Jesus by John the Baptist. The baptism of Jesus is seen as the first firm historical point of departure to construct the life of Jesus. Yet, also, this probable historical 'fact' is retold in mythical terms. The narratives in the canonical gospels relate that during Jesus' baptism, a voice from heaven called Jesus a child of God. The earliest Jesus faction in Jerusalem regarded Jesus as the 'messiah' and 'son of man', but connecting the concept 'son of God' to Jesus' baptism cannot be traced back to the Jesus-followers in Jerusalem. Where did this practice originate?

To call Jesus the 'son of God' may be related to the concept of 'royal messianism' in Hebrew Scriptures of which, among others, Psalm 2 bears witness. The usage of this concept in a 1st-century Israelite context, however, is rather rare (e.g. the use of Psalm 2 in Ac 4:25-26 and the Qumran literature $4 \mathrm{Q}$ Florilegium 10-14). There is, however, not sufficient reason why it should be accepted that the first Jesus-followers in Jerusalem associated the 'Christological' titles 'Son of God' and 'Messiah' with each other - especially in the connection between the concept 'royal messianism' and the baptism of Jesus by John the Baptist. Paul was also not acquainted with the association of Jesus' baptism and the declaration that Jesus is the 'son of God'. In Romans 1:3-4, Paul associates such a proclamation with belief in the resurrection. Historically, critical exegetes have pointed out that naming Jesus the 'son of God' was a projection by the post-Easter Jesusfollowers into the pre-Easter Jesus tradition as if it was made during the baptism of Jesus (Mk 10:11) and on the so-called mountain of transfiguration (Mk 9:7) (cf. also Funk 1998:106; Schmithals 1972:398-401). In this instance, the Gospel of Mark serves as a source for the other synoptic gospels (Matthew and Luke). The critical question is whether this 'naming of Jesus' should be seen as the roots of common Christian confessional language.

To profess means to verbalise a fundamental religious experience. Mark's experience was based on Jesus' experience to be a child of God. This experience is reported in Mark, inter alia, by the 
instances in which Jesus addresses the God of Israel as Abba. In a sense, the Gospel of Mark begins and ends with the narrative about this experience. At the beginning (as a kind of heading for the document Mk 1:1), the author refers to the

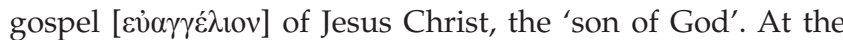
end, the episode of Jesus in the Garden of Gethsemane is narrated, in which it occurs three times that Jesus calls God Abba. An example is Mark 14:36, where Jesus said: 'Abba, Father', and then in Mark 15:39, at the death of Jesus, the Roman centurion exclaims: '[s]urely this man was the son of God' (Mk 15:39).

The words of Jesus' prayer that Mark chooses to use in this context in the episode of Gethsemane (Mk 14:36) are a typical request by the oldest son of his father during a meal (see Derrett 1979:308-315). The boy asks if there could not be somebody else at the table, such as a visiting family head, more worthy than the oldest son (somebody of greater honour and therefore a higher status). The boy asks whether the cup cannot perhaps pass him by and be given to someone else, who should receive the cup from the father before him.

The narration about the sleeping disciples (Peter, John and James) in the Garden of Gethsemane was Mark's answer to this question. It appears as if Mark knew that these disciples were aware that, after the death of Jesus, they would play leadership roles in the Jesus-movement in Jerusalem and that Mark resisted their possible abuse of power by reminding them of Jesus' role as a servant (see Mk 10:35-45).

These staunch supporters of the Jesus-movement in Jerusalem (see Paul in Gl 2:9) should therefore not be thinking too highly of themselves: whoever wants to be a 'man of the moment' must be prepared to be the 'servant' of

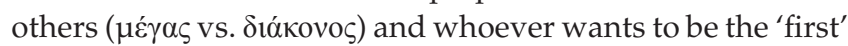
among you must become 'everybody's slave' ( $\pi \rho \tilde{\omega} \tau$ ¿ $\varsigma$ vs.

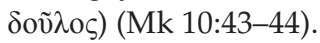

The Christological portrayal with regard to the 'servant' or 'deacon' role of Jesus is related to the early tradition according to which the crucifixion and resurrection of Jesus are to be understood soteriologically. This tradition is known as the kerygmatic tradition. According to this tradition, Jesusfollowers are brought into the right relationship with God, in that they, by some or another symbolic means, become part of Jesus' death and resurrection - a participative idea that I would like to express with the term unison as in the title of the article. Paul says that the believer has been crucified with Jesus ( $\mathrm{Rm}$ 6:6). He refers to this as a baptism that symbolises dying and rising with Jesus (see Rm 6:3-4). Against the background of the kerygmatic tradition, Mark 10:45 refers to Jesus' suffering and death as a sacrifice of life

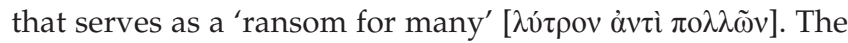
kerygma that the suffering Jesus is the 'son of God' who has paid with his blood in order that peoples of all ethnicities can be 'ruling priests' is found expression imaginatively in Revelation 5:6-14. Already, when at the beginning of
Revelation 'redemption by the blood of Jesus' is mentioned, there is reference to the 'redeemed' as 'kingdom' and 'priests' of God (Rv 1:5b-6a).

Notable in this context is the reference to God as the 'father' of Jesus. Just as in the case of the Gethsemane episode in the Gospel of Mark, the kerygmatic tradition also links Jesus' suffering to the filiation of Jesus (especially cf. Rm 1:3-4; Mk 15:39). Although the kerygmatic tradition is the product of the earliest Jesus-movement in Jerusalem and as the religious conviction regarding the suffering 'son of God' as told in Mark is understood, the confession that God is the 'father of Jesus' can substantially be traced back to Jesus himself.

It could be accepted with great historical probability that the historical Jesus called the God of Israel 'father'.

Such a form of address, and the rich content on which it has a bearing, is an important component of the coherent picture that humankind has formed, based on the New Testament. The conviction that Jesus proposed God as the father is historically confirmed by multiple, independent and early literary testimonies (see Gospel of Thomas 99 and Mk 3:31-35; Sayings Source Q 10:21;11:2; Lk 23:34, 46; Mt 26:42; Jn 11:41, 12:27-28, 17:1, 5, 11, 21, 24-25; cf. Funk \& Hoover 1993:148-149; Jeremias [1971] 1971:62; Patterson 1998:103-104; Wright 1996:648). Geza Vermes (1993) refers to this representation of God as follows:

Perhaps the most paradoxical aspect of the teaching on the kingdom of heaven which can safely be accredited to Jesus is that, unlike the God of the Bible and of intertestamental and rabbinic literature, the God of Jesus is not a regal figure, but is modelled on a smaller, hence more accessible, scale. He is conceived in the form of the man of influence familiar to Jesus and his listeners, the well-to-do landowner and paterfamilias of rural Galilee ... The Synoptic Gospels depict him [Jesus] as addressing God, or speaking of him, as 'Father' in some sixty instances, and at least once place on his lips the Aramaic title, Abba. That the idea is essential for the accurate perception of the religion of Jesus is beyond question. (pp. 146, 163)

To call somebody 'father' implies a begetting by the father. However, we do not find in Mark (as also with the earliest post-Easter faction of the Jesus-followers in Jerusalem) any tradition about the conception and birth, about who could possibly be his father and about the history of his childhood.

Aspects about this may well be found in the gospels of Luke and Matthew (and in apocryphal documents that further elaborate on the elements of the canonical gospels). A historical-critical reading of these gospels, compared to other early Christian literature, suggests that Matthew and Luke took over the belief from the 'Jerusalem faction' that God accepted Jesus as Israel's messiah. Matthew and Luke related this tradition to the information in the Gospel of Mark that Jesus (on the occasion of his baptism by John the Baptist) was confirmed as the son of God - a perspective, which we have argued, that did not originate with the earliest faction of Jesus-followers in Jerusalem. 
According to Matthew and Luke, God accepted Jesus as the 'son of God' at his birth. They repeat this confession when they report on the baptism of Jesus, as if the readers of Matthew and Luke only at that time learned of Jesus' real identity. According to Paul (see Rm 1:3-4), only on the occasion of the resurrection of Jesus from the dead was there, as it were, a public announcement (based on the triumph of the 'spirit of holiness' over the 'spirit of falsehood' (see 1 QS 4 [Serek Hayahad/'Rule of the Community'], in Vermes 1987:66; cf. Collins 1996:221) that Jesus, because of his vindication over death, was called the 'son of God'. For Paul, spirit $[\pi v \varepsilon \tilde{v} \mu \alpha]$ stands against flesh [ $\sigma \alpha ́ \rho \xi]$. He differentiates between

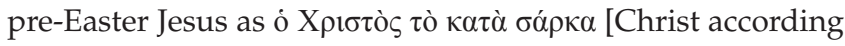

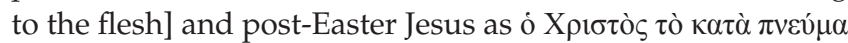
[Christ according to the spirit] (see also Rm 9:1-5), which can be viewed as the first signs of an opinion that Jesus has two 'natures'.

\section{Footprints of religious language}

In the circles of creedal Christianity, the teaching about the 'two natures' of Jesus is today almost only understood in an ontological sense and in terms of the 'teachings about the Trinity'. Ontology is by definition a phenomenon that concerns relational association, but theologically seen, not only in the sense of the 'Trinitarian' relationships. The latter refers to 'relational ontological' thinking about the nature of Jesus Christ in relationship to the Father and the Holy Spirit and it goes back to the 3 rd -4 th century CE. It was a time that was especially, since the 20 s of the 4 th century, characterised by the interference of the Roman Emperor Constantine (282-337 CE) in matters of the church. Constantine ruled from 285 CE until his death on 22 May 337 CE (see Grant 1971:253-279). On the initiative and insistence of the emperor, an ecumenical council (First Council of Nicaea 325 CE) (Asia Minor) was organised in Nicaea. The purpose of the gathering was especially to settle disputes between the bishop of Alexandria, Alexander and Arius (especially about the point of view with regard to the relationship between 'godliness' and 'humanness' in the 'person' of Jesus). Especially with the support of the orthodox Eastern bishops, the council took a decision against Arius' conviction with their compilation of an ecumenical confession of faith (i.e. the Nicaean creed). The motive of the emperor, however, was not only of a religious nature, but certainly also a political one (see Grillmeier 1979:387). In light of both, the threatening rift of the 'Holy Roman Empire' between an eastern-based Byzantine church and a western-based Roman church, and the political pressure from the Germanic tribes and the Persians, the emperor wanted to establish and maintain political unity by means of theological rulings.

Whether Constantine really understood the issues and made the Sache Jesu his own is doubtful. A year after Nicaea, in AD 326 , he had his wife, Fausta (the daughter of the non-Christian ruler Maximias, whom he had married to increase his chances of becoming emperor), and his son, Chrispus, killed. He had already had his father-in-law, Maximias, murdered in 310
CE. He also had no qualms to allow a representation of the Eleusinian mystery religion to go on an official pilgrimage to Egypt in 326 CE. In $327 \mathrm{CE}$, he acquitted Arius and his supporter Eusebius of Nicomedia (brother of Eusebius, orthodox bishop of Caesarea) on the accusation of heresy. The year before his death (336 CE), he discharged Athanasius (who was the secretary of bishop Alexander during the Nicaean conciliate) and banned him from Alexandria (see Grant 1990:225-227).

The ontological-metaphysical Christological question in creedal Christianity focuses primarily on the 'divine nature' (being) and not on the 'human nature' (being) of Jesus. It has therefore become known as a 'Christology from above'. The emphasis lies more on the judgement of 'Being' rather than on the judgement of 'values'. Athanasius, the bishop of Alexandria, described the last-mentioned as 'economical' which refers to Jesus' work (in German: Würdeprädikationen) (see Meijering 1974). This theology only emerged in the 19th century, especially since Albrecht Benjamin Ritschl (18221889) began to be more interested in Jesus' Wurdepriidikationen. Karl Barth ([1952] 1972:658) describes Ritschl as the opponent of all metaphysics in theology. In an English translation of Barth's description of the 19th-century Protestant theology, reference is made to Ritschl's view of the relationship between Jesus and God, and referred to it as follows (Barth 1972):

Now the object of human experience, which has for man the value of Godhead, and concerning which, therefore, in a certain sense we can venture to pronounce: 'He is God' - this object, and therefore the occasion for the knowledge of God as the God of love, is the historical phenomenon Jesus of Nazareth. Jesus, himself being in surpassing fashion the bearer of grace as well as of dominion over the world, is the archetypal image of the humanity which is to be united in the kingdom of God and his vocation to reveal the God who is love. (p. 661)

In Reformed orthodoxy, this ontological-metaphysical interest is being maintained unabridged. It investigates, describes and explains the similarity (one-in-being) of the being of the personae (Father, Son and Holy Spirit) in the Trinity in terms of their mutual relationships of Being. Here the emphasis falls differently than with, for example, Philippus Melanchthon (1497-1560) who said that to know Jesus is to know his actions of mercy - in other words, it is enough to know what Jesus did, without knowing the secret of his person. Also, Immanuel Kant (1724-1804) had, with his critical question about the possibility of the scientific knowledge of metaphysics, asked for practical and analogical use of language.

The epistemological revolution caused by Kant went hand in hand with the rise of the historical criticism in the field of biblical scholarship. New Testament scholars have since then preferred to refer to the perspectives of Jesus as the Christ by the writers of the New Testament as being 'functional' in nature. The 'titles' of Jesus are seen as metaphors that make value assessments with regard to Jesus. The so-called 'Christological titles' used for Jesus by the New Testament authors are in other words not recorded as assessments of Being. 
Consequently, the focus from this perspective was on the behaviour and function of Jesus that can be understood from his words and deeds. It was his behaviour and function that caused the post-Easter followers of Jesus to think about him in a distinct way and that gave him 'honorary titles' to describe his behaviour and function. With a theological approach (known as 'functional Christology') that investigates degrees of continuity between the 'proclaiming' pre-Easter Jesus and the 'proclaimed' post-Easter Jesus, the title 'Christ' (an example of an honorary title) has come into being in the historicalcritical paradigm. As distinct from the 'Christology from above' of the ontological-metaphysical approach, the 'functional approach' of the 'Christology from below' became an argumentative enterprise of exegetes engaged in New Testament scholarship. Historical-critical exegetes are convinced that the New Testament does not contain evidence of a 'metaphysical ontological Christology' (see, among others, Bultmann [1951] 1952:248) - although the genealogy of Christology originated textually in the New Testament and, pre-New Testament, the historical Jesus' affinity with God renders, philosophically seen, an 'ontological' relationship.

Besides a 'Christology from above' and a 'Christology from below', also a 'Christology from the side' can be distinguished. This approach is not interested in Jesus' conduct and thereby to show continuity or discontinuity between the pre-Easter Jesus and the post-Easter kerygma. It investigates the probable experiences of those around the historical Jesus (followers or rivals) in terms of the impact that his words and deeds had on the social context of the 1st-century Mediterranean world. It therefore does not ask for the nature of the confession of their post-Easter creed on the basis of, for example, their own experiences or those of others of the resurrection appearance. Yet, it does not follow naturally that the Jesus-followers, only after they had 'seen' the risen Jesus, became aware of God's presence in the life of Jesus or their own lives.

For the 1st-century Mediterranean world, all 'natural' matters were influenced by either divine or demonic forces. The acknowledgement that Jesus is the son of God (e.g. Rm 1:4; Mk 15:39) and has not been possessed by Baäl-Zebub (see Mk 3:20-30; Mt 9:32-34, 12:22-26; Lk 1:14-18) is linked by the earliest witnesses (Paul and Mark) to the kerygma about the death and resurrection of Jesus. It is this kerygmatic tradition that led to creedal Christianity's view that Jesus manifests both godliness and humanness.

However, this tradition, found in confessions of the postEaster Jesus-followers, was expressed through myths and metaphors of religious experiences between God and humankind, and not primarily in terms of Greek philosophical categories. This fundamental experience historically goes back in all probability to fundamental experiences in the life of the historical Jesus himself. From Paul's letters (and in a certain sense also the author of the Gospel of John, among others), one can infer that Paul was not of the opinion that this experience was unique to Paul himself or even to Jesus, although Paul referred to Jesus in Romans 8:29 as the 'firstborn among many brethren'
[ $\pi \rho \omega \tau$ ó sense. One could refer to it as a 'collective personality'. Paul spoke about a similar experience that other Christ-followers who called themselves 'children of God' had experienced. In this context, he used the metaphor 'adoption' that is an acceptance of the filiation of God.

The origin of this metaphor goes back to the Graeco-Roman culture in which consanguinity between father and child was not, as in the Mediterranean world of the Israelites, regarded as of great importance. Children born outside of a specific family context were easily adopted as 'own' children. Paul redefines on the strength of this influence the expression 'children of Abraham', so that it should not be understood in the biological sense, but rather spiritually (see also Mt 3:9; Jn 1:13). Christ-followers, who descended from non-Israelite ethnicities, could therefore also become part of God's housekeeping. About 30 years after Paul wrote his letter to the Romans, the author(s) of the Gospel of John formulate this same matter in a similar manner when they distinguish between 'natural birth' and 'spiritual birth' (see Jn 3:5).

It seems that each time the early church recalled the virgin conception confessionally, the intention was to communicate the message strongly that Jesus was undoubtedly human. The problem in the Graeco-Roman context during the 2nd century was not so much that a person was declared divine. The Greeks and Romans frequently regarded heroic figures or emperors (of whom myths about benefaction shown to humankind were proven and from where miraculous procreations and/or experiences of resurrection from the dead originated) as gods or demigods (see Koester 1992:10-13; Sissa 1990:73-86). The conviction that a 'god' or 'son of god' could be of humble descent and suffer a horrible death, like that of Jesus of Nazareth, was therefore considered to be an affront. ${ }^{1}$ The emphasis in the early Christian apologetic confession against 'Gnosticism' and 'Ebionism', as well as the Greek mythology and Roman emperor cult, was to widen the confession that Jesus is God, to the confession that Jesus, the son of God, is also human being. This emphasises the conviction of the early and later Christ-followers that Jesus is imparted into humankind, but unlike the heroic or royal figures of the times (see Koester 1992:13-15), not in a primary biological-familial sense of the word.

\section{Language and experience: Footprints of dogma}

The historical proses that lie behind the development of a confessional language are related to the manner in which religious language originated and developed (Ricoeur 1974:26, 38, 42-43). It is important in this context to take note of the epoch-making work of the Swiss linguist, Ferdinand De Saussure ([1915] 1966), in which it is shown that the concept of 'language' must be understood in a multifarious manner, meaning that there are multiple 'meanings'

1.See, for example, Seneca's view on the Emperor Claudius against the background of the defamation of Jesus of Nazareth by Celsus, written c. 175 to 177 CE (cf. Callagher 1982:49, 611). 
embedded. From the perspective of deconstruction, the postmodern philosopher Jacques Derrida (1972) opposes De Saussure's 'logocentric' and 'structuralist' accentuation on the action of the spoken over the written word [ecriture] (see Govinden 1994:139-141). This does, however, not detract from the fact that De Saussure's terminological distinction between the terms langage, parole and langue is still usable.

Langage is the broadest aspect because it includes the entire human potential for speech, both physical and mental. As such, it is simply too broad and undefined an area to be studied systematically. Langue, however, is defined precisely by virtue of its systematic qualities. For langue is a specific 'language' as we use the word in speaking about the English 'language' or the French 'language'. Langage is the language system that each of us uses to generate discourse that is intelligible to others. Our individual utterances are what Saussure calls parole. Thus, langage is linguistic potential, langue is a language system and parole is individual utterance (Scholes [1974] 1978:14).

Martin Turnell (cited in Johnson [1971] 1976:282) defines langage (Sprache) as an 'amalgam of the beliefs, custom, habits, social attitudes, and conventions that are current in the writer's milieu'. The term 'language' is therefore not something that only refers to a specific language such as English, German or French.

'Language' is an expression of experience. The use of language (parole) is characterised by specific articulation.

Aspects such as style belong to this category. 'Religious language' is a specific aspect of the human potential for speech, both physical and mental, and it distinguishes itself, for example, from 'philosophical discourse' (although a 'religious discourse' cannot but make use of philosophy, in other words, anthropological-phenomenological categories). Religious language (langage) is the physical verbalisation of religious experience.

Religious experience is an individual matter. It is peculiar, personal - a unique person's encounter with God.

The only possible way in which to describe and interpret this encounter is to use a metaphorical language. In other words, religious language speaks about God's encounter with the human being to objectify the relation with the assistance of conceptual objects that originate from the living environment of humankind. However, God is not an object - the Creator rises above Creation, although Creation breathes the 'Spirit of the Creator'.

In theology (in the sense of speaking about and from God in relation to the human being, in other words, God-talk), God cannot be represented in any other way than by images from human experience. Metaphorical language is another example of 'figurative use of language' (parole). Poets, for example, freely use figurative language. Figurative use of language is a metaphor when the use of language enters the field of language. This happens when the use of language exceeds the borders of individual usage. If a group of people acknowledge the power of expression of metaphorical language, the specified picture from human experience has become a metaphor and the relevant image can be shown lexicographically as a metaphor with the possibility of a specific reference. Metaphors are the synchronic use of language (compared to figurative parole of an individual which is diachronic use of language) bound to a specific time and culture.

Religious experience does not remain to be an intimate and unique feeling. It appeals to be shared. Moreover, when shared, religious experience is expressed in the figurative use of language. The religious experience of individuals is particularly private and personal. On the other hand, worship (a cultic activity that is characterised by specific rites) is not only personal but simultaneously group-oriented. For that reason, language, which is the religious expression of a group of people (in other words, bound to time and culture), will mainly consist of metaphoric (synchronic) use of language. When this metaphoric use of language becomes a stereotypic use of language (in other words, when it is 'standardised'), it means that it has already adopted some form of confessional formula(s).

A credo is a language that has the potential to function across boundaries of time and culture, relevant for people other than the group of individuals with whom the religious experience initially originated. When a credo becomes a regular, stereotyped confession with a normative connection to time and culture, it assumes the form of dogma. If confessional formulae function abstractly, timelessly and permanently, they are usually regarded and used as doctrines (dogmas). Adogmatic doctrine implies the transfer (i.e. 'tradition') of a specific 'truth'. The consideration of the truth goes hand in hand with what a specific group of people see as being the truth. This implies cognitive consensus and opposes the variety of opinions. Dogma represents distancing (that Ricoeur 1974:26 calls in compliance with Heidegger's existentialist view, Entfernung) of individual subjective experience. However, because of the potentiality of 'dogma' to yield to be normative irrespective of its time of origin and its original cultural and geographical setting, dogma becomes to be langage that has the potential to be used as a tool to manipulate, to marginalise and to eliminate people who hold on to other belief patterns. ${ }^{2}$

In other words, the complex origin and development of dogma implies four simple phases. It represents a movement from a:

- fundamental religious experience, to

- use of language, to

- confessional formulae, to

- dogma.

A 'deconstruction' of the 'dogmatics' with regard to the 'twonature' being of Jesus in relation to the Godhead leads to the

2.Wethmar (2002), in an article entitled 'Does dogma have a future, refers to such a disaffecting unfortunate development of the use of the concept 'dogma' as follows disaffecting, unfortunate development of the use of the concept 'dogma' as follows - explaining it as an 'overemphasis of the legal element in faith': 'This development became particularly clear during the Constantinian era when Christianity became state religion. This situation caused the tenets of faith to become propagated with the authority of the laws of the state. Whenever this happens the nature of the resulting faith is not a comprehensive spiritual and existential event any more but faith reduced to formal obedience' (Wethmar 2002:289). 
question as to the fundamental experience of the historical man called Jesus of Nazareth.

Through my research of the historical Jesus, I developed a way of seeing of what the fundamental experience of God as the 'father' in the life of Jesus might have been. I described this point of view in terms of the concepts of inclusivity and egality - concepts that I call 'evangelical values' ensuing from the $\tilde{\eta} \theta$ o $\varsigma$ of Jesus and his $\beta \alpha \sigma \imath \lambda \varepsilon i \alpha$ ethics. These values contain the message that all people have equal access to the grace of God. The adjectives 'all' and 'equal' have reference to the evangelical values of, respectively, inclusivity and egality. Those were values that stood in sharp contrast to the conventional views that were traditionally accepted in the time of Jesus. In this time, Israel had a very specific, fundamental experience of God, which can be referred to as a 'politics of holiness' over against the 'politics of compassion' to be found in the disposition of Jesus of Nazareth.

Authentic existence beyond the borders of the Promised Land was subject to difficulty. God was viewed in an exclusive manner, only accessible to Israel as an extended biological family. An encounter with God was considered only to take place within a specific cultic space, the Jerusalem temple (or in Pharisaic paradigm, the synagogue as replication of the temple and its purity ideology). In the inner chambers of, respectively, the 'Holy' and 'Holiest' of the Jerusalem temple were God's redeeming acts, according to this way of thinking, carried out by the agency of priests within the hierarchy prescribed by Israel's legal and religious codes. As a consequence, the siege of Jerusalem, destruction of the temple brought with it traumatic crisis in religious experience. In the paradigm of thought of the apocalypse, this crisis easily gave rise to escapism and poured itself out into a wish for a heavenly utopia.

The historical Jesus grew up in 'Galilee of the gentiles' (see Mt 4:15). His way of speaking about God was filled with metaphors that reflected the world of the rural population in Galilee. It testified to an experience that was not conventional. His stories about how, in unusual ways, God is a king, as well as those about his healings, were metaphors in which Jesus expressed his experiences of God's limitless and immediate presence with all people. Jesus used an image that related to an exceptional intimate relationship of his time, namely, the Father-Son relationship. In 1st-century Mediterranean culture, a father who had no son did not have either honour or dignity, and a son without a father had no honour or identity. Jesus' use of this symbol questioned the core of the culture of his time. In this hierarchically organised society, the patriarch represented his family before God. Not one of the members of the family could claim to experience God's presence without being embedded in the sphere of the biological father.

It is therefore notable that Jesus did not use the term 'father' to portray access to God, but the child (cf. Gospel of Thomas 22:1-2; Mt 10:13-16, 19:13-15; Jn 3:1-10). Who is not like a child does not experience God's presence. Jesus' view is actually more radical than what it appears on the surface.
He did not have children whose father did not legitimise them ('adopted' is the word in the Graeco-Roman sense of the word), as a metaphor in mind. In Mark 10:13-16, Jesus referred to illegitimate 'fatherless street children' as a symbol of those who belong to the kingdom of God (see Schmithals 1986:447-448). ${ }^{3}$

It appears here as if Jesus expressed a fundamental, religious experience from his own life in word and deed. Jesus acted in terms of the prophetic tradition (see, e.g., Is 1:16-17) as the protector of fatherless children, women (inter alia widows) who were not under the protective sphere of a patriarch; strangers and 'bastards' (e.g. the Samaritans), who could not claim 'rights' for the same care as men who were biologically part of the covenant of 'Abraham's children'. In the Hebrew Scriptures, the righteousness of God has frequently been described in terms of a command to do 'justice' to such people. ${ }^{4}$ His concern with the marginalised did not happen from a position as of 'from above', but from a position of being one of their own. Jesus did not only address God as the 'father'. Jesus lived among the marginalised, as though he and the outcasts were children of God - in other words, Jesus saw himself as these people's fictitious brother.

A strong case can be made that it was really this aspect of the Sache Jesu that was the reason that so many people in such a short time in the Mediterranean world joined the Jesusmovement. After all, more than $45 \%$ of the inhabitants of the Roman Empire were slaves. Moreover, slaves were people who, by reason of the Sache Jesu, received the right to become part of the family of God, because they no longer were mere slaves, but especially brothers in the Lord (see Phlp 6-17) - in other words, children of God with a divine hereditary right (see Rm 8:14-29). In the Graeco-Roman world, it was a rather strange idea that slaves, after their death, should become part of the families of the gods.

As the Jesus ethos increasingly spread all the more - a movement literally not only in the spatial, but also in the metaphorical sense, which could be described as a movement to Jerusalem from Jerusalem - the metaphor 'child of God' became part of the use of the language (langage) of the Jesusfollowers. They experience God's presence by reason of their participation of Jesus, the son of God. The rhetoric of the Gospel of John can be described in terms of this perspective. The readers (listeners) of the gospel are persuaded not to place their highest trust in Jesus, who is, according to tradition, the (physical) son of Joseph, but to base their faith in Jesus, the (spiritual) son of God (see Jn 6:37-40, 20:30b), who does not provide 'ordinary bread' for the world, but the 'bread that comes from heaven' (Jn 6:33). Whoever sees Jesus in this manner sees the 'Father' (Jn 14:8). The apparent intention of such a rhetoric (which was possibly formulated in terms of the Platonic-Stoic philosophy - see

3.The baptismal liturgy that 'parents' brought their children to Jesus is not supported by the textual evidence in the New Testament. No mention of 'parents' occurs. Jesus blessed street urchins.

4.See $1 \mathrm{Sm}$ 8:14-18; Am 2:6-8, 10-12; 8:4-7; Hs 6:6, 12:7-9; Is 1:10-17, 3:14-15; M 2:2, 3:1b-3, 6:6-8; Jr 7:5-7, 7:9-11; Ezk 45:9-12; Zch 7:9-19. 
Dodd 1953:98, 107-108) could be that the humanness of Jesus should not be seen as a stumbling block to experience God's presence when the Jesus kerygma is being proclaimed (see Bultmann [1955] 1970:20-21, 40-42, 46-49).

Seen from the perspective of the Platonic-Stoic philosophy, the divine essence does not consist of the materially visible, but the 'pneumatic' that cannot be perceived with the physical eye. According to the Gospel of John, the risen Jesus says to him (which is not bound by space - see Jn 20:26): ‘[b] ecause you have seen me, you have believed; blessed are those who have not seen and yet have believed', and Jesus'

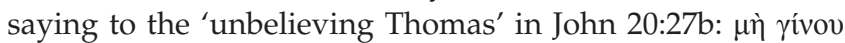

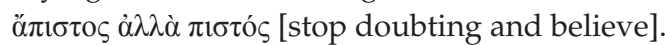

Thomas' confession follows 'O Kúpió Emperor and God]. Although this type of metaphoric use of language (langage) has been formulated according to Greek philosophy, the use of the metaphor 'son of God' - and even the equation between Jesus with God (and Emperor) - in these texts is functional in nature and not ontological. In the New Testament, the focus is on what Jesus and the Jesusfollowers did. The New Testament narrates about the proclaimer who became the proclaimed - about Jesus who called God of Israel, 'Father', and of Jesus-followers who called Jesus the 'son of God'. After the New Testament, these 'events' concerning Jesus' filiation developed into a dogma. A functional metaphor became an ontological metaphor. Whatever had reference to the 'natural life' now became a 'supernatural' matter.

In the New Testament, the references to the 'two natures' of Christ-followers - analogous to the 'natures' of the kerygmatic Jesus - function to emphasise their human and spiritual origin. In the times after the New Testament and the Council of Nicaea, this type of metaphorical use of language (langage) became an expression of Jesus' 'relationship of being' with the heavenly Father - a static, abstract category of being. The concept 'two natures' therefore derived its origin from the metaphorical use of language. It was an expression of the fundamental experience that nothing physical or cultural in character could prevent God's spiritual and immediate presence. Human beings are 'reborn' as children of God because of their sharing of the filiation of Jesus in relationship to the God of Israel. This dualnature metaphor developed into a confessional formula and later into an unquestioned established dogma of Jesus' two natures in terms of the concept 'Triune God'.

\section{From dogma to experience and confession}

A deconstruction of dogma implies that the building blocks of dogma should be noticed. This strategy distinguishes four phases: the (i) fundamental religious experience that (ii) is expressed by the metaphorical use of language, which (iii) transitions into confessional formulae and which (iv) devolves to fixed dogmas. Deconstruction of dogma does not as such require that confessional formulae that preceded the establishment of dogma should be regarded as obsolete.
The aim is not to harm the 'doctrine that is expressed in the confession' [harmonia confessionis doctrinae evangelicae declarans].

To profess faith is after all, in recollection of a previous 'yes', once again to say 'yes' and not to undo the previous 'yes'. Yet, the new 'yes' can never be the same as the previous 'yes'. Deconstruction undermines fusion of the signifier with the signified. In a certain sense, we have to do with a paradoxical 'yes-no'. To again say 'yes' is to displace the previous 'yes' with a 'no', because the ideal (which is only possible in thought) did not realise and can only be but desired. The ideal cannot be realised, because we ourselves, our langage, our culture and our own interests are stumbling blocks.

Deconstruction therefore has, as 'engaged' hermeneutics, both a positive and a negative responsibility. It is especially in the determination of dogmas that interest in power play begins to fulfil a role. Of course, in all communication, certain stumbling blocks are experienced. On the positive side, spotting of successive stacking of building blocks will show the relevance of the dogma or the lack thereof. The positive goal has two questions in mind: are metaphors (bound to a specific time and culture) in which fundamental religious experience has been expressed still functional? Are the confessional formulae used, the most suitable carrier (tradition) of the relevant fundamental, religious experience?

In unison with the Christological teaching of creedal Christianity (from the time since the Nicaean Council until the Council of Chalcedon), notwithstanding my 'critical' commentary about Jesus that sounds contradictory to the 'Trinitarian' structure of the 4th-century Symbolum Apostolicum, based on the 2nd-century Vetus Symbolum Romanum, and notwithstanding my critical commentary about the New Testament proclamation concerning Jesus, I believe that Jesus shared the same substance as that of the Godhead. This, to me, means that the 'Incarnate Word' - a Johannine metaphor - is not, under certain conditions, 'God in the flesh' and under other conditions 'God not in the flesh'. For me, this confession stands firm, amidst my awareness of the complexity of the historical background of these pronouncements about the pre-existence, his existence and post-existence of Jesus in the teachings of creedal Christianity.

However, whilst in unison with creedal Christianity, as far as the New Testament is concerned, I unashamedly differentiate between the 'historical Jesus' and the 'proclaimed Christ'. Yet, I understand the 'pre-Easter' Jesus and the 'post-Easter' Jesus as two-in-one, distinguished from each other, but not separated. This opinion does, in my view, not contradict the teaching of the early church which emphasises that the humanness of Jesus not for one moment exists outside of the union with the 'divine Logos'.

I acknowledge the inadequacy of the church in the past and present to try to define the mystery and being of God (Belgic Confession Article 9). Nevertheless, I believe in the triune God: one being, three persons. I, together with creedal Christianity, confess the 'one being' of God the Father, as 
Son and as Holy Spirit. Concerning Jesus, I cannot confess the godliness of Jesus independently of Jesus' humanness. Together with the 'orthodox church', I confess the godliness and the humanness of Christ Jesus as unadulterated (nonconfusum) and undivided (conjunctum) as well as in one person (in una persona). Just as Jesus does not share all the characteristics of the Godhead (and the Holy Spirit), in a particular sense the 'post-Easter' Jesus, that is 'Jesus of faith' over against the 'historical Jesus', does not share all the attributes of humankind. Jesus as a human being, that is

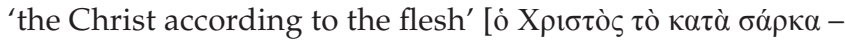
Rm 9:5], is not of eternity ('not of all times') and 'is made $\sin ^{\prime}$ (2 Cor 5:21).

According to the Nicene Creed, the godliness of Jesus implies infusion by God at birth, and therefore, 'begotten' and 'not made'. According to the Heidelberg Catechism (Article 33), Jesus permeated by God implies that he can be described as 'the eternal, natural son of God'; and according to the Belgic Confession (Article 10), Jesus, 'born from eternity', is without $\sin$ and saved us from sin (Heidelberg Catechism Article 29). On the one hand, the Belgic Confession (Article 8) states that the godliness of Jesus presupposes that the 'Father was never without his Son (and his Spirit)'; on the other hand, the Athanasian Creed (Articles 29-32) states that Jesus is equal to the Father (aequalis Patri) only concerning his godliness, but that he is not equal to the Father (minor Patre) regarding his humanness.

What the confession of the church teaches in this regard is, on the one hand, that Jesus' godliness is not independent of his humanness, and, on the other hand, that the person of the 'Father' in the dogma of the triune God is the 'beginning of all things'. However, the Son (who is the 'image of the Father') does not share these qualities, although Father and Son with regard to 'wisdom, goodness (i.e. 'justice') and mercy' - are of 'equal eternity one and the same being' (Belgic Confession Article 8).

\section{An epilogue about anathematisation and heresy}

Seen from a particular perspective, the beginning of the 'formalisation' of creedal Christianity goes back to the Nicaean Council. In the first draft of the Nicaean creed, those who do not accept the joined substance between Jesus and the Godhead (homoousion to patri) were regarded by the 'catholic church' as having 'anathematised' themselves (see Simmons 2010:38). This 'anathematisation' (from the Greek $\dot{\alpha} v \alpha \dot{\theta} \theta \varepsilon \alpha)$ did not intend ecclesiastical excommunication as it was understood in works from the 6th century onwards. This later understanding was that a person who was declared anathema was deemed a 'heretic' (apostate) who was cut off from fellowship with 'orthodox' Christians and from God.

The earlier understanding correlated with the use of the Greek word anathema [ $\alpha v \alpha \dot{\theta} \varepsilon \mu \alpha]$ in the New Testament where it appears six times, five times in the letters of Paul (1 Cor 12:3, 16:22, Gl 1:8, 9; Rm 9:3) and once in the Acts of the apostles (Acts 23:13). The context is that of opposition against Paul. The translation of $\alpha v \alpha \dot{\theta} \theta \varepsilon \mu \alpha$ as 'curse' or in the sense of 'excommunication' is not the semantic denotation of the New Testament usage of the word. It is probably related to the Hebrew word סרת [cherem] which occurs some 50 times in the Hebrew Scriptures as a verb and some 30 times as a noun. Its semantic connotation differs. Sometimes, the context is that of 'holy war' and sometimes that of 'ritualised killing'. The commonality is the reference to a threat to the integrity of the religious community. The 'extermination' has a 'religious element to it so that what was destroyed was understood to be "devoted" to God and therefore belonged to God' (Bratcher 2011).

Paul's usage is not necessarily pejorative in the sense of 'curse'. According to 1 Corinthians 12:3, Jesus cannot be 'anathema'. His was not a killing in the sense of cherem in order that his opponents could 'give him back to God'. When he was killed, God resurrected him in order for him to live for God (to be devoted to God) (see Simmons 2010:39-40). The other occurrences in Paul's letters also do not have the connotation of 'curse'. The usage of 'anathematisation' in the Nicaean creed is closer to Paul's understanding than to the later ecclesiastical usage.

In Paul's letters, the term 'heresy' also did not have the connotation that it acquired in later ecclesiastical practice. An early example of the later usage can be seen in the treatise Adversus haereses of Irenaeus, bishop of Lyon, written in c. 180 $\mathrm{CE}$ as an apology against 'gnostic-minded' followers of Jesus. In the later usage, a 'heretic' is labelled an apostate who should be excommunicated from the fellowship of believers or even cut-off from God. For example, in 1 Corinthians 11:19,

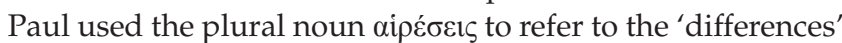

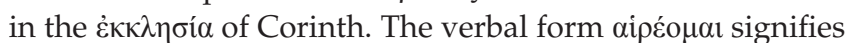
an act of making a choice (see Louw \& Nida 1988:361) in a context where divergent opinions or options exist. In

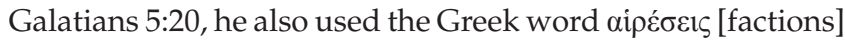

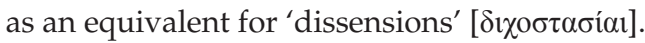

Those who differed from Paul's understanding of gospel

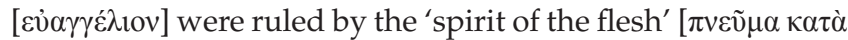

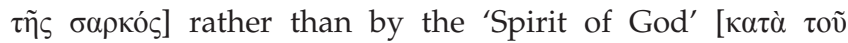
$\pi v \varepsilon v ́ \mu \alpha \tau o \varsigma]$. In the 2nd-century text, 2 Peter (2:1), the term 'heresy' came to signify 'destructive' teachings of 'false prophets' and 'false teachers' who brought 'destruction' on themselves.

John of Damascus uses the term 'orthodox faith' in the title of his treatise, De fide orthodoxa (written c. $650 \mathrm{CE}$, before $755 \mathrm{CE}$ ). This 'orthodox faith' refers to Jesus sharing the same substance with God, namely, wisdom, justice and mercy. The notion 'orthodox faith' is not used as in an ecclesiastical context where 'heterodoxy' is cursed with anathematisation and heretics are

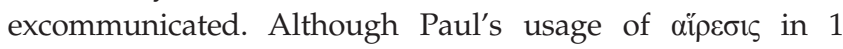
Corinthians 11:29 and Galatians 5:20 is embedded in a middlePlatonic binary paradigm (cf. Brandenburger 1968; Dillon [1977] 1996; Wasserman 2008:409-410), for me orthodoxy does not imply a binary distinction between 'right and wrong', 'me 
and you', 'us and them', 'blessed or anathema' (cursed) or 'orthodoxy versus heresy'. To me, orthodoxy simply means 'identity' among other 'identities' - or in a more collective sense, 'communion' in community among other 'communities'.

My partiality to Athanasius of Alexandria (296-373 CE) and John of Damascus (676-749 CE) is not a deliberate choice either against Alexander of Alexandria (313-326 CE or 313$382 \mathrm{CE}$ ) or against Arius of Alexandria (256-336 CE), as it was the case of the pre-Nicaean and post-Nicaean ecclesiastical councils. It is rather a position of 'orthodoxy deconstructed' where orthodoxy is stripped off any form of binary thinking. It is constructed in unison with Friedrich Schleiermacher and Rudolf Bultmann. It is about continuity in substance between Jesus and Paul (and John, among other New Testament authors), irrespective of their discontinuity in content. In conclusion, this sameness in substance, rooted in the Sache Jesu, was formulated by the Nicaean Creed and later confirmed by the Athanasian Creed.

To conclude, my aim was to argue that the sharing of 'being' between Jesus and the Godhead, professed in creedal Christianity and based on the Nicaean creed, pertains to a 'sameness in divine substance'. This substance refers to divine wisdom, justice and mercy. This article attempts to demonstrate that there exists a congruence between textual evidence in the New Testament and these 'orthodox' belief tenets, especially represented in the Athanasian creed.

\section{Acknowledgements Competing interests}

The author has declared that no competing interest exist.

\section{Author(s)contributions}

I declare that I am the sole author of this article.

\section{Ethical consideration}

This article followed all ethical standards for a research without direct contact with human or animal subjects.

\section{Funding Information}

This research received no specific grant from any funding agency in the public, commercial or not-for-profit sectors.

\section{Data availability statement}

Data sharing is not applicable to this article as no new data were created or analysed in this study.

\section{Disclaimer}

The views and opinions expressed in this article are those of the author and do not necessarily reflect the official policy or position of any affiliated agency of the author.

\section{References}

Barth, K., [1952] 1972, Protestant theology in the nineteenth century: Its background \& history, transl. J. Bowden, SCM, London.

Brandenburger, E., 1968, Fleisch und Geist: Paulus und die dualistische Weisheit, Wissenschaftliche Monographien Zum Alten und Neuen Testament, 29, Neukirchener, Heidelberg.

Bratcher, D., 2011, Devoted to destruction, viewed 25 March 2019, from http://www. crivoice.org/terms/t-herem.html.

Bultmann, R., [1955] 1970, Theology of the New Testament, vol. 2, transl. K. Grobel, SCM, London.

Callagher, E.V., 1982, Divine man or magician? Celsus and Origen on Jesus, SBL Dissertation Series 64, Scholars Press, Chico, CA.

Collins, A.Y., 1996, 'The origin of Christian baptism', in A.Y. Collins (ed.), Cosmology \& eschatology in Jewish \& Christian apocalypticism, pp. 218-229, Supplements to the Journal for the Study of Judaism, Brill, Leiden.

Derrett, J.D.M., 1979, 'Haggadah and the account of the passion', The Downside Review 97(329), 308-315, https://doi.org/10.1177/001258067909732905

Derrida, J., 1972, 'Structure, sign, and play in the discourse of the human sciences', in E. Donato \& R. Macksey (eds.), The structuralist controversy: The language of criticism and the sciences of man, John Hopkins University Press, Baltimore, MD.

De Saussure, F., [1915] 1966, Kursus in Algemene Taalkunde, C. Bally (ed.), transl. A. Lee, Van Schaik, Pretoria.

Dillon, J., [1977] 1996, The middle-Platonists 80 BC to 220 AD, Cornell University Press, Ithaca, NY.

Dodd, C.H., 1953, The interpretation of the Fourth Gospel, Cambridge University Press, Cambridge.

Funk, R.W., 1998, The acts of Jesus: What did Jesus really do? The search for the authentic deeds of Jesus, Harper, San Francisco, CA.

Funk, R.W. \& Hoover, R.W., 1993, The five gospels: The search for the authentic words of Jesus, Macmillan, New York.

Govinden, B., 1994, 'The search for meaning: Creating a dialogue between literature and theology', in J. Mouton \& B. Lategan (eds.), The relevance of theology for the 1990s, pp. 137-157, HSRC, Pretoria.

Grant, R.M., 1971, Augustus to Constantine, Harper \& Row, New York.

Grant, R.M., 1990, 'Constantine the Great', in E. Ferguson (ed.), Encyclopedia of early Christianity, pp. 225-227, Garland Publishing, New York.

Grillmeier, A., 1979, Jesus der Christus im Glauben der Kirche, Band 1: Von der apostolischen Zeit bis zum Konzil von Chalcedon (451), Herder, Freiburg.

Jeremias, J., 1971, New Testament theology, Volume one: The proclamation of Jesus, transl. J. Bowden, SCM, London.

John of Damascus, [650 CE, before 755 CE] 1989, 'An exposition of the Orthodox faith' in P. Schaff \& H. Wace (eds.), Nicene and post-Nicene fathers, Second Series, vol. 9. Christian Literature Publishing Co., Buffalo, revised and edited K. Knight, viewed 27 April 2019, from http://www.newadvent.org/fathers/3304.htm.

Johnson, A.M., [1971] 1976, 'Glossary of formalist and structuralist terms', in A.M Johnson (ed.), The New Testament and structuralism: A collection of essays by Corina Galland, Claude Chabrol, Guy Vuillod, Louis Marin and Edgar Haulotte Pittsburgh Theological Monograph Series, pp. 251-322, Pickwick, Pittsburgh, PA.

Louw, J.P. \& Nida, E.A. (eds.), 1988, Greek-English lexicon of the New Testament based on sematic domains, volume 1: Introduction \& domains, United Bible Societies, New York.

Meijering, E.P., 1974, Orthodoxy and Platonism in Athanasius: Synthesis or antithesis? Brill, Leiden.

Patterson, S.J., 1998, The God of Jesus: The historical Jesus \& the search for meaning, Trinity Press International, Harrisburg, PA.

Ricoeur, P., 1974, 'Philosophische und theologische Hermenebtik', in P. Ricoeur \& E. Jilngel (eds.), Metapher: Zur Hermeneutik religioser Sprache, pp. 24-44, Chr Kaiser Verlag, Milnchen, Evangelische Theologie Sonderheft.

Schmithals, W., 1972, 'Der MarkusschluB: Die Verlklärungsgeschichte und die Aussendung der Zwolf', Zeitschrift für Theologie und Kirche 69, 379-411.

Schmithals, W., 1986, Das Evangelium nach Markus: Kapitel 9, 2-16, 18. 2 edn., Gütersloher Verlagshaus Gerd Mohn, Gütersloh, (Ókumenischer TaschenbuchKommentar zum Neuen Testament 2/1).

Scholes, R., [1974] 1978, Sctructuralism in literature: An introduction, Yale University Press, New Haven, CT.

Simmons, T., 2010, 'Between the way to the cross and Emmaus: Deconstructing identity in the 325 CE Council of Nicaea and "the Shack"', MA in English thesis, Gardner-Webb University, viewed 26 March 2019, from https://digitalcommoms. gardner.webb.edu/english_etd/7.

Sissa, G., 1990, Greek virginity, transl. A. Goldhammer, Harvard University Press, Cambridge, MA.

Van Aarde, A.G., 2001, Fatherless in Galilee: Jesus as Child of God, Trinity Press International, Harrisburg, PA.

Vermes, G., 1987, The Dead Sea Scrolls in English, 3rd edn., Penguin, New York.

Vermes, G., 1993, The religion of Jesus the Jew, Fortress, Minneapolis, MN.

Wasserman, E., 2008, 'Paul among the philosophers: The case of $\sin$ in Romans 6-8', Journal for the Study of the New Testament 30(4), 387-415. https://doi. org/10.1177/0142064X08091441

Wethmar, C.J., 2002, 'Does dogma have a future', In Luce Verbi 36(2), 281-291. https://doi.org/10.4102/ids.v36i2.509 